\title{
sciendo
}

\section{EFFECT OF ENCAPSULATED COSMOS CAUDATUS LEAF EXTRACT ON THE PHYSIOLOGICAL CONDITIONS, IMMUNE COMPETENCY, AND ANTIOXIDATIVE STATUS OF BROILERS AT HIGH STOCKING DENSITY}

\author{
Ikania Agusetyaningsih, Endang Widiastuti, Hanny Indrat Wahyuni, Turrini Yudiarti, Retno Murwani, Tri Agus Sartono, Sugiharto Sugiharto*
}

\author{
Department of Animal Science, Faculty of Animal and Agricultural Sciences, Universitas Diponegoro, \\ Semarang, Central Java, Indonesia (50275) \\ •Corresponding author: sgh_undip@yahoo.co.id
}

\begin{abstract}
The present study aimed to investigate the effect of encapsulated Cosmos caudatus leaf extract on the physiological conditions, immune competency, and antioxidative status of broiler chickens raised at a high stocking density. After 15 days of rearing, 370 Lohmann broiler chicks were assigned to five treatment groups, including T0 (chicks were raised at a density of $10 \mathrm{birds} / \mathrm{m}^{2}$ and received no additive), T1 (chicks were raised at a density of $16 \mathrm{birds} / \mathrm{m}^{2}$ and received no additive), T2 (chicks were raised at a density of $16 \mathrm{birds} / \mathrm{m}^{2}$ and received $0.5 \mathrm{~g} / \mathrm{kg}$ encapsulated $C$. caudatus leaf extract), T3 (chicks were raised at a density of $16 \mathrm{birds} / \mathrm{m}^{2}$ and received $1.0 \mathrm{~g} / \mathrm{kg}$ additive), and T4 (chicks were raised at a density of $16 \mathrm{birds} / \mathrm{m}^{2}$ and received $1.5 \mathrm{~g} / \mathrm{kg}$ additive). On days 28 and 42 , blood samples from two chicks per pen were collected. On day 42, the chicks that had been blood-sampled were sacrificed, and blood samples and lymphoid organs (i.e., bursa of Fabricius, spleen, and thymus) were collected. The daily weight gain and feed efficiency of broilers $(\mathrm{P}<0.01)$ in groups $\mathrm{T} 2$ and $\mathrm{T} 3$ were higher than those of broilers in groups T0, T1, and T4. Daily feed intake was greater $(P<0.01)$ in groups $\mathrm{T} 0$ and T1 than in groups T2 and T3. The erythrocyte content and hematocrit value of groups $T 1, T 2, T 3$, and $T 4$ were greater $(P<0.05)$ than those of group T0. The mean corpuscular hemoglobin concentration in group $\mathrm{T} 4$ was lower $(P<0.05)$ than that in groups $\mathrm{T} 0, \mathrm{~T} 1$, and $\mathrm{T} 2$. Leukocyte and lymphocyte levels were higher in group T1 $(\mathrm{P}<0.05)$ than in other groups. Serum albumin was higher in chicks reared at a high density $(\mathrm{P}<0.05)$ than in chicks reared at a normal density. Lesion scores were higher in group $\mathrm{T1}(\mathrm{P}<0.05)$ than in other groups. Chicks in groups T1 and T2 showed more severe pathological changes in their bursa of Fabricius compared with those in groups T0, T3, and T4. Serum superoxide dismutase was higher in groups T2, T3, and T4 $(\mathrm{P}<0.05)$ than in groups T0 and T1. Chicks in group T4 had higher $(\mathrm{P}<0.05)$ malondialdehyde levels than chicks in other groups. In conclusion, a high stocking density influences the metabolic rate and physiological conditions of broiler chicks, as reflected by alterations in the blood profiles of the animals. Stress due to a high stocking density could damage the bursa of Fabricius, but feeding with encapsulated $C$. caudatus leaf extract, especially at a rate of $1.5 \mathrm{~g} / \mathrm{kg}$, could alleviate the cortical and lymphocyte cell depletion of broilers. Regardless of the stocking density effect, dietary supplementation with encapsulated $C$. caudatus leaf extract at doses of 0.5 and $1.0 \mathrm{~g} / \mathrm{kg}$ could improve the daily weight gain of broilers.
\end{abstract}

Key words: broiler, Cosmos caudatus extract, encapsulation, high stocking density

Broiler chicken (Gallus gallus domesticus) is a type of chicken with fast-growing features, high feeding efficiency, and high-quality meat production. The consumption of broiler chicken worldwide has rapidly increased in recent years in line with the growth of the human population (USDA, 2020). Thus, broiler producers must increase the productivity and efficiency of broiler farming to meet escalating demands for chicken meat, possibly by applying higher stocking densities during broiler production (Abudabos et al., 2013). Unfortunately, while the practice shows some benefits, a high stocking density could also trigger oxidative stress and exert a negative impact on the production performance, health, and wellbeing of broilers (Simitzis et al., 2012; Li et al., 2019).

Earlier studies demonstrated that stress due to high stocking densities could increase the ratio of heterophils to lymphocytes (Astaneh et al., 2018), deplete lymphoid cells (Yanai et al., 2018), and decrease IgG and IgM pro- duction (Palizdar et al., 2017) and antibody titers against Newcastle disease (ND) vaccine (Houshmand et al., 2012). Hosseini-Vashan et al. (2015) reported that stress due to a high stocking density decreases uric acid and antioxidant enzyme levels. Sugiharto et al. (2019) suggested that molecular changes due to stress can increase the production of free radicals or reactive oxygen species (ROS) and, thus, trigger oxidative stress in broilers. Dietary supplementation with synthetic antioxidants to reduce the negative impact of oxidative stress is common in broiler rearing practices (Salami et al., 2015). However, the long-term excessive use of synthetic antioxidants, such as butylated hydroxytoluene and butylated hydroxyanisole, may be toxic and pose a risk to consumers' health (Taghvaei and Jafari, 2015; Zhou et al., 2019). As such, the use of natural antioxidants is recommended to minimize the application of synthetic antioxidants in broiler chickens. 
Recent literature shows that plant extracts contain numerous phenolic compounds that can function as antioxidants (Reddy et al., 2018). Cosmos caudatus Kunth is a plant species that has been documented to contain high levels of antioxidants (Liliswarianis et al., 2011; Reihani and Azhar, 2012). Traditionally, this species is widely used as a medicinal plant for humans (Saleh et al., 2020). The leaf of $C$. caudatus Kunth is rich in phenolic components, including (per $100 \mathrm{mg}$ ) $51.28 \mathrm{mg}$ of quercetin, $4.54 \mathrm{mg}$ of chlorogenic acid, and $3.64 \mathrm{mg}$ of caffeic acid. The leaves also contain $64.6 \mathrm{mg}$ of ascorbic acid and 3,568 $\mu \mathrm{g}$ of $\beta$-carotene per $100 \mathrm{~g}$ of fresh sample (Cheng et al., 2015).

Many studies have shown that supplementation of phenolic compounds into dietary rations increases the body weight gain and enzymatic and non-enzymatic antioxidant levels of broilers and layers (Kim et al., 2015; Iskender et al., 2016). However, phenolic compounds in plant extracts are generally unstable during storage (Trucillo et al., 2018). As such, further attempts to prevent the oxidation of phenolic compounds in plant extracts, for example, through encapsulation, are needed (Pang et al., 2014; Jeyakumari, 2016). Encapsulation is a method of covering products with coating materials to improve shelf life by preventing bioactive components from degradation. Encapsulation may preserve the taste or smell of a product and reduce fungal growth (Mishra, 2016). To date, the use of encapsulated $C$. caudatus Kunth leaf extract to alleviate the negative impact of stress due to a high stocking density has not been reported. Dietary supplementation of encapsulated C. caudatus leaf extract is hypothesized to improve the physiological conditions, immune system, and antioxidant status of broilers reared at a high stocking density. Thus, the present study aims to investigate the effect of encapsulated $C$. caudatus leaf extract on the physiological conditions, immune competency, and antioxidative status of broiler chickens raised at a high stocking density.

\section{Material and methods}

\section{Production of encapsulated Cosmos caudatus leaf extract}

Production of the encapsulated extract commenced with the extraction of $C$. caudatus leaf. C. caudatus leaves were purchased from traditional markets in Semarang, Central Java, Indonesia, weighed, washed, cleaned, and drained. The leaves were dried indoors to avoid exposure to direct sunlight until their water content was less than $10 \%$. The dry leaves were then ground to obtain a fine powder and extracted at a leaf powder:solvent (70\% ethanol) ratio of 1:6 (Karimy et al., 2013). The dry C. caudatus leaf powder was immersed in ethanol for 72 $\mathrm{h}$ at room temperature and then filtered through filter paper to obtain a filtrate. The filtrate was concentrated with a vacuum rotary evaporator at a maximum temperature of $60^{\circ} \mathrm{C}$ to obtain the paste form of C. caudatus leaf extract (Vongsak et al., 2012).

Encapsulation of C. caudatus leaf extract was accomplished by freeze-drying. The coating material used for encapsulation, maltodextrin, was dissolved in distilled water at a ratio of 1:3. The dissolved maltodextrin was mixed with the filtrate of $C$. caudatus leaf extract at a ratio of $5: 1$, and the mixture was freeze-dried to obtain the encapsulated $C$. caudatus leaf extract powder.

\section{Animals and experimental diets}

A total of 370 Lohmann broiler chicks with an average body weight of $41.2 \pm 0.76 \mathrm{~g}$ from a commercial hatchery were used in this study. The chicks were raised in a broiler house with a litter floor (rice husk) and manual feeders and drinkers. A commercial starter diet containing $21 \%-23 \%$ crude protein, $5 \%-8 \%$ fat, $3 \%-5 \%$ crude fiber, and $4 \%-7 \%$ ash (proximate data were obtained from the feed manufacturer) were provided to the chicks during the brooding period (1-14 days). On days 15-42, the chickens were provided with a formulated diet (Table 1) containing different doses of the encapsulated C. caudatus leaf extract. Drinking water was provided ad libitum throughout the rearing period.

Table 1. Ingredients and nutritional composition of broiler diets provided on days $15-42$

\begin{tabular}{lc}
\hline \multicolumn{1}{c|}{ Items $(\%)$} & Composition \\
\hline Yellow maize & 57.9 \\
Palm oil & 2.55 \\
Soybean meal & 34.8 \\
DL-methionine & 0.19 \\
Bentonite & 1.00 \\
Limestone & 1.34 \\
Monocalcium phosphate & 1.51 \\
Premix ${ }^{2}$ & 0.27 \\
Chlorine chloride & 0.07 \\
Salt & 0.40 \\
Chemical compositions: & \\
metabolizable energy $(\mathrm{kcal} / \mathrm{kg})^{1}$ & 3.386 \\
crude protein & 20.8 \\
crude fiber & 3.53 \\
crude fat & 2.39 \\
ash & 6.96 \\
\hline
\end{tabular}

${ }^{1}$ Metabolizable energy was calculated according to the Bolton formula: $40.81\{0.87$ [crude protein +2.25 crude fat + nitrogen-free extract] +2.5$\}$

${ }^{2}$ Premix containing (per kg of diet) Vitamin A 7750 IU, Vitamin D $1550 \mathrm{IU}$, Vitamin E $1.88 \mathrm{mg}$, Vitamin $\mathrm{B}_{1} 1.25 \mathrm{mg}$, Vitamin $\mathrm{B}_{2} 3.13 \mathrm{mg}$, Vita$\min B_{6} 1.88 \mathrm{mg}$, Vitamin $B_{12} 0.01 \mathrm{mg}$, Vitamin C $25 \mathrm{mg}$, folic acid $1.50 \mathrm{mg}$, Ca-D-pantothenate $7.5 \mathrm{mg}$, niacin $1.88 \mathrm{mg}$, biotin $0.13 \mathrm{mg}$, Co $0.20 \mathrm{mg}, \mathrm{Cu}$ $4.35 \mathrm{mg}$, Fe $54 \mathrm{mg}$, I $0.45 \mathrm{mg}$, Mn $130 \mathrm{mg}$, Zn $86.5 \mathrm{mg}$, Se $0.25 \mathrm{mg}$, L-lysine $80 \mathrm{mg}$, choline chloride $500 \mathrm{mg}$, DL-methionine $900 \mathrm{mg}, \mathrm{CaCO}_{3} 641.5 \mathrm{mg}$, and dicalcium phosphate $1500 \mathrm{mg}$.

On day 4, all chicks were vaccinated with active ND-infectious bronchitis vaccine (Caprivac ND-R ${ }^{\circledR}$, PT. Caprifarmindo Laboratories, Indonesia) through 
eye drop or inactive ND-avian influenza (AI) vaccine (Caprivac ND-AI K ${ }^{\circledR}$, PT, Caprifarmindo Laboratories) through subcutaneous injection at a dose of $0.15 \mathrm{ml} / \mathrm{head}$. Gumboro vaccine (Cevac Transmune IBD ${ }^{\circledR}$, Ceva Animal Health, Indonesia) was given on day 14 through the drinking water.

From day 15 onward, the chickens (average body weight, $447.4 \pm 5.22 \mathrm{~g}$ ) were allocated into five treatment groups, including T0, T1, T2, T3, and T4, with five replicate pens in each group. The birds in $\mathrm{T} 0$ were reared at a density of 10 birds $/ \mathrm{m}^{2}$ (i.e., normal stocking density), while the birds in $\mathrm{T} 1, \mathrm{~T} 2, \mathrm{~T} 3$, and $\mathrm{T} 4$ were reared at a density of 16 birds $/ \mathrm{m}^{2}$ (i.e., high stocking density). Chicks in groups T0 and T1 were not provided with encapsulated C. caudatus leaf extract or other supplements. Birds in groups T2, T3, and T4 were fed with diets containing encapsulated $C$. caudatus leaf extract at doses of $0.5,1.0$, and $1.5 \mathrm{~g} / \mathrm{kg}$, respectively.

Feed intake and the body weight gain of the broilers were measured weekly from day 15 to day 42 . On days 28 and 42, two chicks per pen were randomly selected for blood sampling through the brachial vein. The collected blood was placed in vacutainers with an anticoagulant (ethylenediaminetetraacetic acid) for complete blood count determination or vacutainers without anticoagulant for serum production. Serum was obtained by centrifugation of the blood samples at 3,000 rpm for 15 min and then stored in a freezer until analysis. At the end of the study (day 42), the two chicks that had been bloodsampled were sacrificed, and their lymphoid organs, i.e., bursa of Fabricius, spleen, and thymus, were collected.

\section{Data collection and laboratory analysis}

\section{Performance of broilers}

Assessment of chicken performance included daily body weight gain, daily feed intake, and feed efficiency measurements. Data on daily weight gain were obtained by weighing the chickens on day 42 (i.e., the final weight), subtracting the initial weight (end of day 14) from the final weight, and then dividing the result by the experimental period ( 28 days). Daily feed intake was determined by dividing the total feed intake by the experimental period (28 days). Feed efficiency was calculated by dividing the body weight during treatment by the feed intake and then multiplying the result by $100 \%$. Feed conversion ratio (FCR) was calculated by dividing the feed intake by the body weight during treatment. In this work, final live body weight and FCR data are reported as mean \pm standard deviation.

\section{Complete blood counts}

Complete blood counts were determined according to the dilution flask procedure, as described by Isroli et al. (2017). The numbers of erythrocytes and leukocytes were calculated, and a Burker chamber was used to count corpuscles. Hematocrit values were calculated using the microhematocrit technique. Differential leukocytes were counted using a light microscope with an immersion lens. The coverslip procedure was applied during blood smear preparation.

\section{Serum protein profile}

Serum total protein was measured by photometric assay on the basis of the biuret process according to the manufacturer's manual. Albumin was measured via the photometric test using a commercial kit (DiaSys Diagnostic Device GmbH, Holzheim, Germany) with bromocresol green (DiaSys, Diagnostic System GmbH). The difference between total protein and albumin levels was measured to obtain globulin levels. Biochemical evaluation of creatinine and uric acid was conducted via the colorimetric/enzymatic color test using the necessary kits (DiaSys Diagnostic Device $\mathrm{GmbH}$ ) according to the manufacturer's instructions.

\section{Lymphoid organ weight and histopathology}

The relative weights of immune organs (i.e., bursa of Fabricius, spleen, and thymus) were determined by measuring the organ weight, dividing the value obtained by the live body weight, and then multiplying the result by $100 \%$. Lymphoid organs were stored in $10 \%$ buffered formalin (Surgipath ${ }^{\circledR}$ ) after weighing. The organs were then fixed in paraffin blocks and sliced to a thickness of $25 \mu \mathrm{m}$ using a microtome for histological examination. Tissue fragments were mounted on a glass slide and stained with hematoxylin and eosin according to the method of Kiernan (2015). The histological structure of lymphoid organs was observed under a light microscope to investigate their pathological changes. The lesions observed were scored according to the severity of tissue damage (Yanai et al., 2018) as follows: 0 (no lesions, 0\%), 1 (mild, 5\%-25\% lesions), 2 (moderate, 26\%-50\% lesions), and 3 (severe, $>50 \%$ lesions).

\section{Antibody titer}

The hemagglutination inhibition (HI) test for ND and AI antibodies was conducted according to Mayo (2002). Twofold serial dilutions of the serum sample were generated in microtiter plates with normal saline. Next, $0.05 \mathrm{ml}$ of the ND or AI antigen was applied to each well of the plate. Three rows of wells were left as controls, the first row contained only the ND antigen (positive control), and the third row contained normal saline with red blood cells. The plate was shaken by a Titertek plate shaker and held at room temperature for $30 \mathrm{~min}$. Afterward, $0.05 \mathrm{ml}$ of red blood cells from the broilers was applied to each well. The highest dilution that could inhibit 50\% agglutination was considered the HI titer.

\section{Antioxidant activity}

Superoxide dismutase (SOD) activity was tested according to the ability of the sample to suppress pyrogallol auto-oxidation. The mixture consisted of $50 \mathrm{mM}$ Tris- $\mathrm{HCl}$ ( $\mathrm{pH} 8.2$ ), $1 \mathrm{mM}$ pentaacetic acid diethylenetriamine, and a sample. The reaction was initiated via the addition of pyrogallol (final concentration, $0.2 \mathrm{mM}$ ), and 
the absorbance was kinetically calculated. SOD concentrations are expressed in units of $\mathrm{U} / \mathrm{ml}$. Malondialdehyde (MDA) activity was measured using the reactive material test for thiobarbituric acid (TBA). Each sample was vortexed, added with $8.1 \%$ sodium dodecyl, and left at room temperature for $10 \mathrm{~min}$; the control was treated in the same manner. After incubation, 20\% acetic acid and $0.6 \%$ TBA were applied to the samples, and the tubes were placed in a water bath for $1 \mathrm{~h}$ at $90-95^{\circ} \mathrm{C}$. Thereafter, butanol:pyridine $(15: 1)$ was applied to the supernatant, and the mixture was vortexed and centrifuged. MDA concentrations are expressed in units of $\mathrm{nmol} / \mathrm{ml}$.

\section{Statistical analysis}

The data obtained were statistically analyzed using one-way ANOVA at the 5\% significance level. Differences among treatment groups were detected by Duncan's multiple range test. Histopathological scores of lymphoid tissues were analyzed non-parametrically using the Kruskal-Wallis method. The data are presented as meanrank. Images of pathological lesions provided in the figures describe the condition of the lesions in each treatment group and are provided for exploratory comparisons only. SPSS version 16.0 software was used for data analysis.

\section{Results}

\section{Growth performance of broilers}

Data on the growth performance of the broilers are presented in Table 2. The daily weight gain and feed efficiency of the broilers were higher in groups T2 and T3 $(\mathrm{P}<0.01)$ than in groups T0, T1, and T4. Daily feed intake was greater in groups T0 and T1 $(\mathrm{P}<0.01)$ than in groups $\mathrm{T} 2$ and $\mathrm{T} 3$ but not different from that in group $\mathrm{T} 4$.

\section{Complete blood counts and serum protein profiles of broilers}

Data on the complete blood counts of the broilers are illustrated in Table 3 . The erythrocyte and hematocrit values in groups T1, T2, T3, and T4 were greater $(\mathrm{P}<0.05)$ than those in group $\mathrm{T} 0$. The mean corpuscular hemoglobin concentration (MCHC) in group $\mathrm{T} 4$ was lower $(\mathrm{P}<0.05)$ than that in groups T0, T1, and T2 but did not differ from that in group T3. Leukocyte and lymphocyte values were also higher in group T1 $(\mathrm{P}<0.05)$ than in the other treatment groups and lowest in groups $\mathrm{T} 0$ and $\mathrm{T} 4$.

Table 2. Performance of broilers (days 15-42)

\begin{tabular}{l|c|c|c|c|c|c|c}
\hline \multicolumn{1}{c|}{ Items } & T0 & T1 & T2 & T3 & T4 & SEM & P value \\
\hline DWG (g) & $70.5 \mathrm{~b}$ & $68.4 \mathrm{~b}$ & $77.5 \mathrm{a}$ & $76.0 \mathrm{a}$ & $68.0 \mathrm{~b}$ & 1.02 & $<0.001$ \\
DFI (g) & $143 \mathrm{a}$ & $145 \mathrm{a}$ & $135 \mathrm{~b}$ & $134 \mathrm{~b}$ & $140 \mathrm{ab}$ & 1.38 & 0.002 \\
FE (\%) & $49.7 \mathrm{~b}$ & $47.2 \mathrm{~b}$ & $57.6 \mathrm{a}$ & $56.8 \mathrm{a}$ & $48.6 \mathrm{~b}$ & 1.05 & $<0.001$ \\
\hline
\end{tabular}

$\mathrm{a}, \mathrm{b}$ - means marked with letters in the same row are significantly different $(\mathrm{P}<0.05)$.

T0: chicks were raised at a density of $10 \mathrm{birds} / \mathrm{m}^{2}$ and received no additive, T1: chicks were raised at a density of 16 birds $/ \mathrm{m}^{2}$ and received no additive, T2: chicks were raised at a density of 16 birds $/ \mathrm{m}^{2}$ and received $0.5 \mathrm{~g} / \mathrm{kg}$ encapsulated Cosmos caudatus leaf extract, T3: chicks were raised at a density of 16 birds $/ \mathrm{m}^{2}$ and received $1.0 \mathrm{~g} / \mathrm{kg}$ encapsulated $C$. caudatus leaf extract, T4: chicks were raised at a density of 16 birds $/ \mathrm{m}^{2}$ and received $1.5 \mathrm{~g} / \mathrm{kg}$ encapsulated C. caudatus leaf extract, SEM: standard error of the mean, DWG: daily weight gain, DFI: daily feed intake, FE: feed efficiency.

Table 3. Complete blood counts of the broilers

\begin{tabular}{|c|c|c|c|c|c|c|c|}
\hline Items & T0 & $\mathrm{T} 1$ & $\mathrm{~T} 2$ & T3 & $\mathrm{T} 4$ & SEM & $P$ value \\
\hline Erythrocytes $\left(10^{6} / \mu \mathrm{L}\right)$ & $2.56 \mathrm{~b}$ & $3.23 \mathrm{a}$ & $3.24 \mathrm{a}$ & $3.17 \mathrm{a}$ & $2.98 \mathrm{a}$ & 0.06 & 0.004 \\
\hline Hematocrit (\%) & $31.9 \mathrm{~b}$ & $40.5 \mathrm{a}$ & $43.2 \mathrm{a}$ & $40.7 \mathrm{a}$ & $38.8 \mathrm{a}$ & 0.94 & 0.001 \\
\hline $\mathrm{MCV}$ & 125 & 126 & 125 & 129 & 132 & 1.08 & 0.149 \\
\hline $\mathrm{MCH}$ & 35.2 & 35.8 & 35.1 & 34.2 & 34.1 & 0.23 & 0.087 \\
\hline $\mathrm{MCHC}$ & $28.5 \mathrm{a}$ & $28.6 \mathrm{a}$ & $28.1 \mathrm{a}$ & $26.6 \mathrm{ab}$ & $26.0 \mathrm{~b}$ & 0.32 & 0.025 \\
\hline RDW-SD & 44.6 & 49.4 & 46.4 & 45.7 & 48.9 & 0.61 & 0.051 \\
\hline RDW-CV & 9.65 & 10.4 & 9.77 & 9.32 & 10.3 & 0.12 & 0.076 \\
\hline MPV & 9.66 & 9.39 & 9.21 & 9.07 & 9.22 & 0.09 & 0.343 \\
\hline PDW & 8.63 & 8.73 & 8.03 & 8.56 & 10.1 & 0.41 & 0.625 \\
\hline Leukocytes $\left(10^{3} / \mu \mathrm{L}\right)$ & $73.6 \mathrm{c}$ & $101 \mathrm{a}$ & $86.9 \mathrm{~b}$ & $87.1 \mathrm{~b}$ & $78.2 \mathrm{bc}$ & 2.11 & $<0.001$ \\
\hline Heterophils $\left(10^{3} / \mu \mathrm{L}\right)$ & 3.15 & 5.60 & 3.65 & 3.85 & 3.11 & 0.34 & 0.124 \\
\hline Lymphocytes $\left(10^{3} / \mu \mathrm{L}\right)$ & $69.9 \mathrm{c}$ & $94.9 \mathrm{a}$ & $83.3 \mathrm{~b}$ & $83.3 \mathrm{~b}$ & $74.5 \mathrm{bc}$ & 1.96 & $<0.001$ \\
\hline Thrombocytes $\left(10^{3} / \mu \mathrm{L}\right)$ & 11.5 & 11.70 & 14.1 & 11.3 & 12.0 & 0.78 & 0.807 \\
\hline
\end{tabular}

$\mathrm{a}, \mathrm{b}, \mathrm{c}-$ means marked with letters in the same row are significantly different $(\mathrm{P}<0.05)$.

T0: chicks were raised at a density of 10 birds $/ \mathrm{m}^{2}$ and received no additive, T1: chicks were raised at a density of 16 birds $/ \mathrm{m}^{2}$ and received no additive, T2: chicks were raised at a density of 16 birds $/ \mathrm{m}^{2}$ and received $0.5 \mathrm{~g} / \mathrm{kg}$ encapsulated Cosmos caudatus leaf extract, T3: chicks were raised at a density of 16 birds $/ \mathrm{m}^{2}$ and received $1.0 \mathrm{~g} / \mathrm{kg}$ encapsulated $C$. caudatus leaf extract, T4: chicks were raised at a density of 16 birds $/ \mathrm{m}^{2}$ and received $1.5 \mathrm{~g} / \mathrm{kg}$ encapsulated $C$. caudatus leaf extract, SEM: standard error of the mean, MCV: mean corpuscular volume, MCH: mean corpuscular hemoglobin, MCHC: mean corpuscular hemoglobin concentration, RDW-SD: red blood cell distribution width-standard discrepancy, RDW-CV: red blood cell distribution width-coefficient of variation, MPV: mean platelet volume, PDW: platelet distribution width. 
Table 4. Serum protein profile of the broilers

\begin{tabular}{l|l|l|l|l|l|l|lc}
\hline \multicolumn{1}{c}{ Items } & \multicolumn{1}{c}{$\mathrm{T} 0$} & $\mathrm{~T} 1$ & $\mathrm{~T} 2$ & $\mathrm{~T} 3$ & $\mathrm{~T} 4$ & SEM & P value \\
\hline Total protein (g/dL) & 5.08 & 5.87 & 5.60 & 5.38 & 5.59 & 0.20 & 0.128 \\
Albumin (g/dL) & $1.22 \mathrm{~b}$ & $1.40 \mathrm{a}$ & $1.38 \mathrm{a}$ & $1.41 \mathrm{a}$ & $1.42 \mathrm{a}$ & 0.23 & 0.003 \\
Globulin (g/dL) & 3.85 & 4.46 & 4.23 & 3.97 & 4.17 & 0.26 & 0.208 \\
Uric acid (mg/dL) & 7.41 & 9.21 & 8.15 & 8.87 & 8.32 & 0.28 & 0.568 \\
Creatinine (mg/dL) & 0.19 & 0.12 & 0.70 & 0.90 & 0.21 & 0.36 & 0.686 \\
\hline
\end{tabular}

$\mathrm{a}, \mathrm{b}$ - means marked with letters in the same row are significantly different $(\mathrm{P}<0.05)$.

T0: chicks were raised at a density of $10 \mathrm{birds} / \mathrm{m}^{2}$ and received no additive, T1: chicks were raised at a density of 16 birds $/ \mathrm{m}^{2}$ and received no additive, T2: chicks were raised at a density of $16 \mathrm{birds} / \mathrm{m}^{2}$ and received $0.5 \mathrm{~g} / \mathrm{kg}$ encapsulated Cosmos caudatus leaf extract, T3: chicks were raised at a density of 16 birds $/ \mathrm{m}^{2}$ and received $1.0 \mathrm{~g} / \mathrm{kg}$ encapsulated C. caudatus leaf extract, T4: chicks were raised at a density of $16 \mathrm{birds} / \mathrm{m}^{2}$ and received $1.5 \mathrm{~g} / \mathrm{kg}$ encapsulated C. caudatus leaf extract, SEM: standard error of the mean.

Table 5. Titers antibodies against Newcastle disease (ND) and avian influenza (AI) vaccines

\begin{tabular}{lcc|c|c|c|ccc}
\hline Items $(2 \log \mathrm{n})$ & $\mathrm{T} 0$ & $\mathrm{~T} 1$ & $\mathrm{~T} 2$ & $\mathrm{~T} 3$ & $\mathrm{~T} 4$ & SEM & P value \\
\hline Day 28 & & & & & \\
NDV & 4.60 & 4.70 & 5.10 & 5.40 & 5.00 & 0.197 & 0.732 \\
AIV & 1.90 & 1.80 & 2.60 & 2.50 & 2.30 & 0.234 & 0.778 \\
Day 42 & & & & & & & & \\
NDV & 5.70 & 6.70 & 6.20 & 6.70 & 6.90 & 0.261 & 0.607 \\
AIV & 3.00 & 4.00 & 2.20 & 2.50 & 2.30 & 0.283 & 0.247 \\
\hline
\end{tabular}

T0: chicks were raised at a density of $10 \mathrm{birds} / \mathrm{m}^{2}$ and received no additive, $\mathrm{T} 1$ : chicks were raised at a density of $16 \mathrm{birds} / \mathrm{m}^{2}$ and received no additive, T2: chicks were raised at a density of $16 \mathrm{birds} / \mathrm{m}^{2}$ and received $0.5 \mathrm{~g} / \mathrm{kg}$ encapsulated Cosmos caudatus leaf extract, T3: chicks were raised at a density of $16 \mathrm{birds} / \mathrm{m}^{2}$ and received $1.0 \mathrm{~g} / \mathrm{kg}$ encapsulated C. caudatus leaf extract, T4: chicks were raised at a density of $16 \mathrm{birds} / \mathrm{m}^{2}$ and received $1.5 \mathrm{~g} / \mathrm{kg}$ encapsulated C. caudatus leaf extract, SEM: standard error of the mean, NDV: Newcastle disease vaccine, AIV: Avian influenza vaccine.

Table 6. Relative immune organ weights of the broilers

\begin{tabular}{lcc|c|c|cc|cc}
\hline \multicolumn{1}{c|}{ Items (\% BW) } & T0 & T1 & T2 & T3 & T4 & SEM & P value \\
\hline Bursa of Fabricius & 0.08 & 0.07 & 0.06 & 0.06 & 0.08 & 0.005 & 0.501 \\
Spleen & 0.16 & 0.12 & 0.13 & 0.12 & 0.16 & 0.014 \\
Thymus & 0.16 & 0.14 & 0.15 & 0.10 & 0.14 & 0.010 \\
\hline
\end{tabular}

T0: chicks were raised at a density of $10 \mathrm{birds} / \mathrm{m}^{2}$ and received no additive, T1: chicks were raised at a density of 16 birds $/ \mathrm{m}^{2}$ and received no additive, T2: chicks were raised at a density of $16 \mathrm{birds} / \mathrm{m}^{2}$ and received $0.5 \mathrm{~g} / \mathrm{kg}$ encapsulated Cosmos caudatus leaf extract, T3: chicks were raised at a density of 16 birds $/ \mathrm{m}^{2}$ and received $1.0 \mathrm{~g} / \mathrm{kg}$ encapsulated C. caudatus leaf extract, T4: chicks were raised at a density of $16 \mathrm{birds} / \mathrm{m}^{2}$ and received $1.5 \mathrm{~g} / \mathrm{kg}$ encapsulated C. caudatus leaf extract, SEM: standard error of the mean, BW: body weight.

Table 7. Histopathological scores of the lymphoid tissues

\begin{tabular}{l|c|c|c|c|rr|rr}
\hline \multicolumn{1}{c|}{ Items } & \multicolumn{1}{c|}{ T0 } & T1 & T2 & T3 & T4 & SEM & P value \\
\hline Bursa of Fabricius & $7.00 \mathrm{~b}$ & $22.50 \mathrm{a}$ & $17.70 \mathrm{a}$ & $8.90 \mathrm{~b}$ & $8.90 \mathrm{~b}$ & 0.168 \\
Spleen & 10.00 & 17.50 & 15.00 & 10.00 & 12.50 & 0.101 \\
Thymus & 12.30 & 17.20 & 8.10 & 15.10 & 12.30 & 0.001 \\
\hline
\end{tabular}

The data are presented as mean-rank. a, $\mathrm{b}$ - mean-rank values marked with letters in the same row are significantly different $(\mathrm{P}<0.05)$.

T0: chicks were raised at a density of $10 \mathrm{birds} / \mathrm{m}^{2}$ and received no additive, T1: chicks were raised at a density of 16 birds $/ \mathrm{m}^{2}$ and received no additive, T2: chicks were raised at a density of $16 \mathrm{birds} / \mathrm{m}^{2}$ and received $0.5 \mathrm{~g} / \mathrm{kg}$ encapsulated Cosmos caudatus leaf extract, T3: chicks were raised at a density of 16 birds $/ \mathrm{m}^{2}$ and received $1.0 \mathrm{~g} / \mathrm{kg}$ encapsulated C. caudatus leaf extract, T4: chicks were raised at a density of $16 \mathrm{birds} / \mathrm{m}^{2}$ and received $1.5 \mathrm{~g} / \mathrm{kg}$ encapsulated C. caudatus leaf extract, SEM: standard error of the mean.

Table 8. Serum superoxide dismutase (SOD) and malondialdehyde (MDA) levels of the broilers

\begin{tabular}{l|c|c|c|c|c|c|c}
\hline \multicolumn{1}{c|}{ Items } & T0 & T1 & T2 & T3 & T4 & SEM & P value \\
\hline SOD $(\mathrm{U} / \mathrm{ml})$ & $24.9 \mathrm{c}$ & $26.9 \mathrm{bc}$ & $27.8 \mathrm{~b}$ & $27.4 \mathrm{~b}$ & $30.0 \mathrm{a}$ & 0.39 & $<0.001$ \\
$\mathrm{MDA}(\mathrm{nmol} / \mathrm{ml})$ & $7.91 \mathrm{~b}$ & $9.19 \mathrm{~b}$ & $7.75 \mathrm{~b}$ & $8.18 \mathrm{~b}$ & $14.5 \mathrm{a}$ & 0.75 & 0.017 \\
\hline
\end{tabular}

$\mathrm{a}, \mathrm{b}, \mathrm{c}-$ means marked with letters in the same row are significantly different $(\mathrm{P}<0.05)$.

T0: chicks were raised at a density of $10 \mathrm{birds} / \mathrm{m}^{2}$ and received no additive, T1: chicks were raised at a density of 16 birds $/ \mathrm{m}^{2}$ and received no additive, T2: chicks were raised at a density of $16 \mathrm{birds} / \mathrm{m}^{2}$ and received $0.5 \mathrm{~g} / \mathrm{kg}$ encapsulated Cosmos caudatus leaf extract, T3: chicks were raised at a density of 16 birds $/ \mathrm{m}^{2}$ and received $1.0 \mathrm{~g} / \mathrm{kg}$ encapsulated C. caudatus leaf extract, T4: chicks were raised at a density of 16 birds $/ \mathrm{m}^{2}$ and received $1.5 \mathrm{~g} / \mathrm{kg}$ encapsulated C. caudatus leaf extract, SEM: standard error of the mean, SOD: superoxide dismutase, MDA: malondialdehyde. 
Serum albumin concentrations were higher $(\mathrm{P}<0.05)$ in chicks reared at a high stocking density than in those reared at a normal stocking density (Table 4). No influence ( $\mathrm{P}>0.05$ ) of stocking density or C. caudatus leaf extract supplementation on the serum concentrations of total protein, globulin, uric acid, and creatinine was noted in the broilers.

\section{Immune competency of broilers}

Data on the antibody titers of the broilers against the ND and AI vaccines are shown in Table 5. The treatments applied had no significant impact on titer antibodies against the vaccines in broilers on both measurement days (i.e., days 28 and 42). Moreover, the treatments showed no effect $(\mathrm{P}>0.05)$ on the relative immune organ weight of the broilers (Table 6). The histopathological scores of the lymphoid tissues of broilers are presented in Table 7. The lesion score of group T1 was higher $(\mathrm{P}<0.05)$ than that of the other treatment groups.
Stocking density affected the structure of the bursa of Fabricius of the broiler chickens. Compared with those in groups T0, T3, and T4, chicks in groups T1 and T2 revealed more severe pathological changes in their bursa of Fabricius. However, the spleen and thymus structures were not affected by the treatments. Figures 1-3 show the histopathological lesions of the lymphoid tissues of the broilers.

\section{Antioxidative status of broilers}

Data on the serum SOD and MDA levels of the broilers are presented in Table 8. SOD levels were higher $(\mathrm{P}<0.05)$ in groups $\mathrm{T} 2, \mathrm{~T} 3$, and $\mathrm{T} 4$ than in group $\mathrm{T} 0$. No significant difference $(\mathrm{P}>0.05)$ in SOD level was observed between groups $\mathrm{T} 0$ and $\mathrm{T} 1$. Compared with those in the other groups, chicks in group T4 revealed the highest $(\mathrm{P}<0.05)$ serum MDA levels.

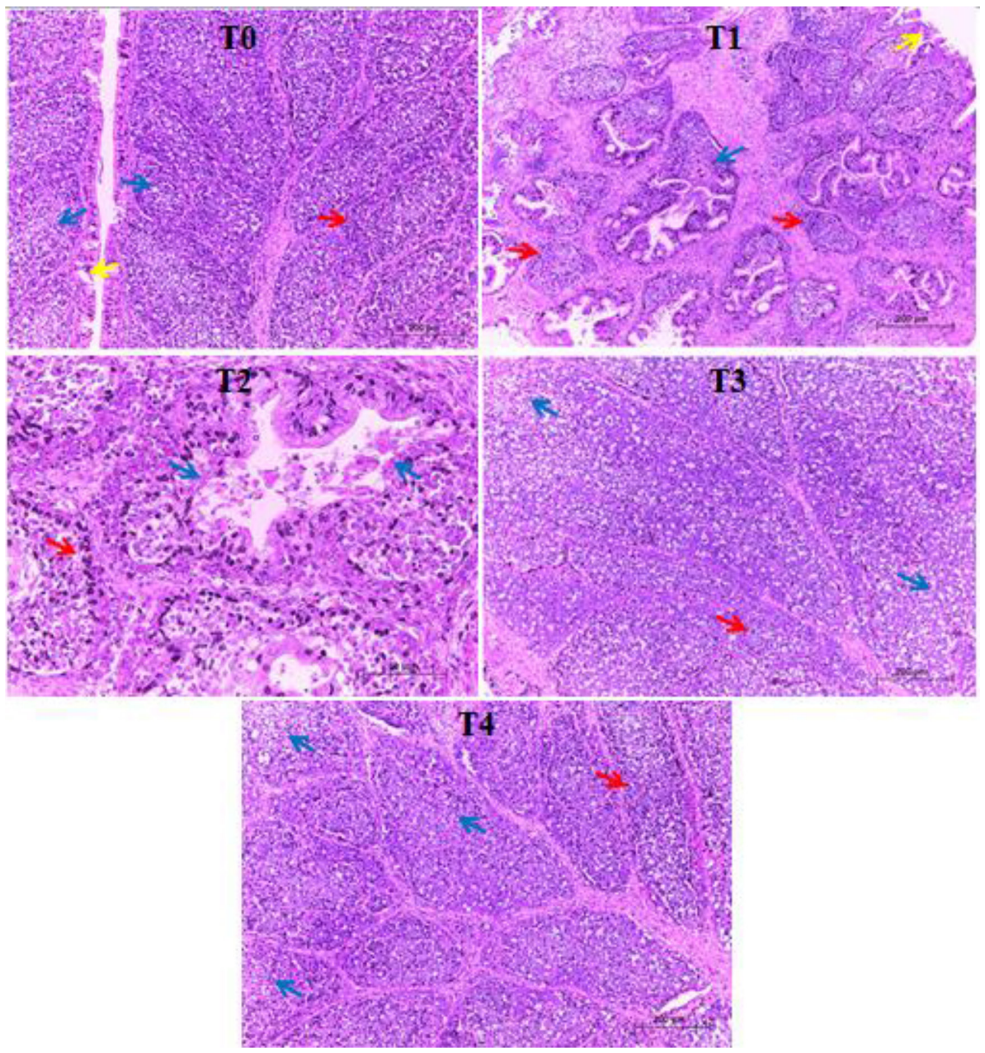

Figure 1. Microscopic photograph of the bursa of Fabricius of broilers on day 42 . T0 (chicks were raised at a density of 10 birds $/ \mathrm{m}^{2}$ and received no additive) showed decreased cortical thickness (red arrow), slight reduction of lymphocyte numbers (blue arrow), and epithelial erosion (yellow arrow). T1 (chicks were raised at a density of 16 birds $/ \mathrm{m}^{2}$ and received no additive) showed decreased cortical thickness (red arrow), severe depletion of lymphocytes in the medulla and cortices with folding of the reticuloepithelial layer (blue arrow), and epithelial erosion (yellow arrow). T2 (chicks were raised at a density of $16 \mathrm{birds} / \mathrm{m}^{2}$ and received $0.5 \mathrm{~g} / \mathrm{kg}$ encapsulated Cosmos caudatus leaf extract) showed decreased cortical thickness (red arrow) and depletion of lymphocytes in the medulla and cortices with folding of the reticuloepithelial layer (blue arrow). T3 (chicks were raised at a density of 16 birds $/ \mathrm{m}^{2}$ and received $1.0 \mathrm{~g} / \mathrm{kg}$ encapsulated C. caudatus leaf extract) showed decreased cortical thickness (red arrow) and moderate depletion of lymphocytes (blue arrow). T4 (chicks were raised at a density of $16 \mathrm{birds} / \mathrm{m}^{2}$ and received $1.5 \mathrm{~g} / \mathrm{kg}$ encapsulated C. caudatus leaf extract) showed decreased cortical thickness (red arrow) and moderate depletion of lymphocytes (blue arrow). Hematoxylin-eosin staining, 100× 


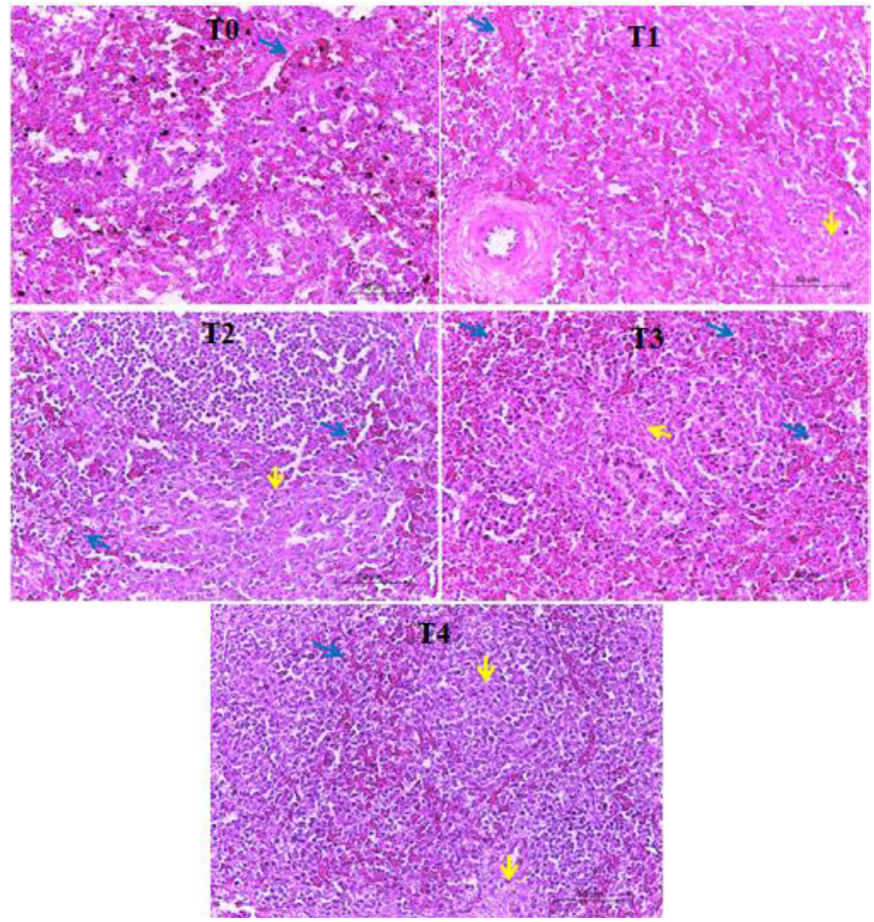

Figure 2. Microscopic photograph of the spleen of 42-day-old chicks. T0 (chicks were raised at a density of $10 \mathrm{birds} / \mathrm{m}^{2}$ and received no additive) showed light hemorrhage (blue arrow). T1 (chicks were raised at a density of $16 \mathrm{birds} / \mathrm{m}^{2}$ and received no additive) showed hemorrhage (blue arrow) and moderate depletion of lymphocytes (yellow arrow). T2 (chicks were raised at a density of $16 \mathrm{birds} / \mathrm{m}^{2}$ and received $0.5 \mathrm{~g} / \mathrm{kg}$ encapsulated Cosmos caudatus leaf extract) showed hemorrhage (blue arrow) and depletion of lymphocytes (yellow arrow). T3 (chicks were raised at a density of $16 \mathrm{birds} / \mathrm{m}^{2}$ and received $1.0 \mathrm{~g} / \mathrm{kg}$ encapsulated C. caudatus leaf extract) showed moderate hemorrhage (blue arrow) and depletion of lymphocytes (yellow arrow). T4 (chicks were raised at a density of $16 \mathrm{birds} / \mathrm{m}^{2}$ and received $1.5 \mathrm{~g} / \mathrm{kg}$ encapsulated C. caudatus leaf extract) showed hemorrhage (blue arrow) and light depletion of lymphocytes (yellow arrow). Hematoxylin-eosin staining, 400×

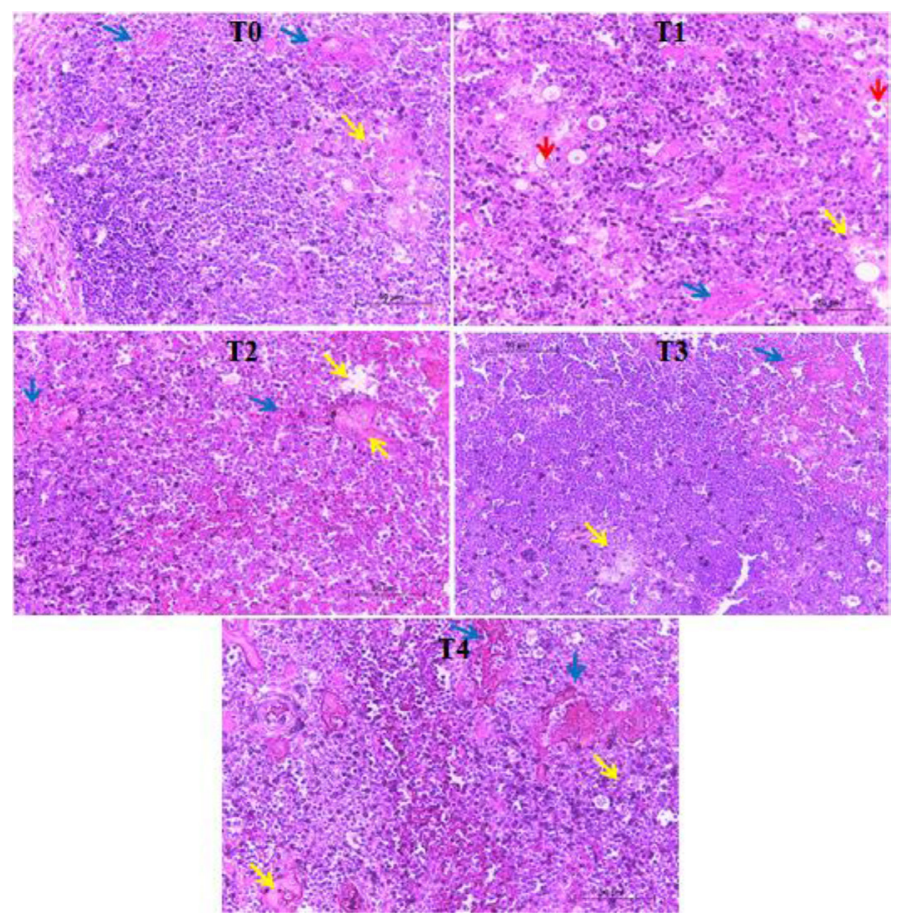

Figure 3. Microscopic photograph of the thymus of 42-day-old broilers. T0 (chicks were raised at a density of $10 \mathrm{birds} / \mathrm{m}^{2}$ and received no additive) showed mild hemorrhage (blue arrow) and lymphocyte depletion in the thymic medulla (yellow arrow). T1 (chicks were raised at a density of $16 \mathrm{birds} / \mathrm{m}^{2}$ and received no additive) showed severe hemorrhage (blue arrow), lymphocyte depletion in the thymic medulla (yellow arrow), and increased numbers of Hassal's corpuscle in the thymic medulla (red arrow). T2 (chicks were raised at a density of 16 birds $/ \mathrm{m}^{2}$ and received $0.5 \mathrm{~g} / \mathrm{kg}$ encapsulated Cosmos caudatus leaf extract) showed mild hemorrhage (blue arrow) and lymphocyte depletion in the thymic medulla (yellow arrow). T3 (chicks were raised at a density of $16 \mathrm{birds} / \mathrm{m}^{2}$ and received $1.0 \mathrm{~g} / \mathrm{kg}$ encapsulated C. caudatus leaf extract) showed light hemorrhage (blue arrow) and lymphocyte depletion in the thymic medulla (yellow arrow). T4 (chicks were raised at a density of $16 \mathrm{birds} / \mathrm{m}^{2}$ and received $1.5 \mathrm{~g} / \mathrm{kg}$ encapsulated C. caudatus leaf extract) showed severe hemorrhage (blue arrow) and mild lymphocyte depletion in the thymic medulla (yellow arrow). Hematoxylin-eosin staining, 400× 


\section{Discussion}

Several studies have documented the association between a high stocking density and compromised growth rate and feed efficiency in broilers (Simitzis et al., 2012; Li et al., 2019). Unlike the aforementioned studies, however, the current study showed no substantial effect of stocking density on the daily weight gain and feed efficiency of broilers. Similarly, Abo-Alqassem et al. (2018) did not find any variations in growth rate and feed conversion among broilers reared at stocking densities of 12 , 15 , or 20 chicks $/ \mathrm{m}^{2}$. Abudabos et al. (2013) observed no substantial effect of stocking densities of 28.0 (low), 37.0 (medium), or $40.0 \mathrm{~kg} / \mathrm{m}^{2}$ (high) on the growth rate, feed intake, and feed conversion of broiler chickens. Several parameters, such as temperature, humidity, and accessibility to feeders and drinkers, may determine the effect of stocking density on the growth performance of broilers. Regardless of the stocking density effect, dietary supplementation with 0.5 and $1.0 \mathrm{~g} / \mathrm{kg}$ encapsulated $C$. caudatus leaf extract increased the daily weight gain of broilers in the present study. On day 42, groups T2 $(2,171 \pm 88.0 \mathrm{~g})$ and T3 $(2,182 \pm 102 \mathrm{~g})$ showed significantly greater final live body weights compared with groups T0 $(1,975$ $\pm 83.9 \mathrm{~g})$, T1 $(1,915 \pm 101 \mathrm{~g})$, and T4 $(1,905 \pm 103 \mathrm{~g})$. FCRs were also higher in groups T2 $(1.73 \pm 0.07)$ and T3 $(1.76 \pm 0.09)$ than in groups T0 (2.02 \pm 0.14$), \mathrm{T} 1(2.12 \pm$ $0.12)$, and $\mathrm{T} 4(2.07 \pm 0.16)$. To date, no study elucidating the growth promoting effect of $C$. caudatus leaf extract on broilers is yet available in the literature. However, bioactive compounds in the leaf extract, such as phenolic components, ascorbic acid, and anthocyanins (Cheng et al., 2015), are believed to affect the growth of broilers in a positive manner.

Data in the present study demonstrated that broilers raised at a high stocking density have higher erythrocyte and hematocrit values than those raised at a normal stocking density. This result contrasts the findings of Park et al. (2018), who noted a decrease in erythrocyte and hematocrit values in broilers reared at a high stocking density. The exact reason for this decrease is not known, but high stocking density-induced stress may be attributed to the acceleration of the metabolic rate of broiler chickens (Selvam et al., 2017). Increases in erythrocyte and hematocrit values in broilers raised at a high stocking density could be an adaptive response to enhancements in metabolic rate, which is accounted to the enhanced carrying capacity of oxygen needed for metabolic processes. Regardless of the high stocking density effect, birds fed diets supplemented with $1.5 \mathrm{~g} / \mathrm{kg}$ encapsulated $C$. caudatus leaf extract revealed decreased $\mathrm{MCHC}$ values. A previous study in pig showed that excessive supplementation of saccharicterpenin, which is derived from Camellia oleifera seed meal, decreases MCHC values, indicating hemolytic anemia in piglets (Wang et al., 2020). Taking this study into consideration, we suggest that dietary supplementation with encapsulated C. caudatus leaf extract, especially at $1.5 \mathrm{~g} / \mathrm{kg}$, may induce hemo- lytic anemia in broilers, which may attenuate the growth promoting effect of encapsulated C. caudatus leaf extract on broilers. This supposition is supported by our finding that birds fed diets supplemented with $1.5 \mathrm{~g} / \mathrm{kg}$ extract have lower daily week gains than birds fed with 0.5 and $1 \mathrm{~g} / \mathrm{kg}$ encapsulated C. caudatus leaf extract. The literature indicates that high stocking densities decrease leukocyte and lymphocyte levels in poultry (Oke et al., 2020). By contrast, our present findings showed that a high stocking density could be associated with increased levels of leukocytes and lymphocytes in broilers. Similar to our results, Nwaigwe et al. (2020) showed an increase in leukocytes and lymphocytes with increasing stocking density stress. The researchers thus suggested that stress due to a high stocking density may increase the activity of noradrenaline, which can activate the generation of hematopoietic stem cells, especially leukocytes.

The present study clearly showed that the serum concentration of albumin is higher in chicks raised at a high stocking density than in those reared at a low stocking density. Similar to our findings, Nwaigwe et al. (2020) and Jeong et al. (2020) revealed that serum albumin concentrations increase in broilers reared at a high stocking density. Indeed, an increase in serum albumin level is a good indicator of physiological stress in broiler chickens (Nwaigwe et al., 2020). Broilers appear to use increases in serum albumin as a means to maintain their metabolic balance in response to high stocking densityinduced stress (Tóthová et al., 2019).

The data in the current study showed no notable effect of treatments on antibody titers toward ND and AI vaccines, as well as the relative weight of lymphoid organs, in broilers. This finding agrees with the findings of Palizdar et al. (2016), who indicated that raising chickens at a high stocking density of $18 \mathrm{birds} / \mathrm{m}^{2}$ has no influence on several immune parameters of broilers, namely, levels of IgG and IgM and antibody responses toward sheep red blood cells. Astaneh et al. (2018) and Houshmand et al. (2012) also revealed that an increase in stocking density has no substantial effect on the relative weight of lymphoid organs (i.e., bursa of Fabricius, spleen, and thymus) and antibody titers against ND vaccine. By contrast, several other studies revealed that high stocking densities decrease the weight of lymphoid organs and antibody titers, thereby compromising the ability of chickens to produce immune cells (Qaid et al., 2016; Gholami et al., 2020). Variations in experimental parameters, such as differences in the numbers of chicks per $\mathrm{m}^{2}$, age, and body weight of chickens, as well as environmental differences, may be responsible for the discrepancies observed among these studies.

Our present findings revealed that broilers reared at high stocking densities show more damage in their lymphoid organs, particularly of the bursa of Fabricius, than those raised at a normal stocking density. This finding is in accordance with the results of Yanai et al. (2018), who showed that broilers reared at densities of 15 and 20 chicks $/ \mathrm{m}^{2}$ experience more severe pathological lesions 
compared with broilers reared at a density of 10 chicks/ $\mathrm{m}^{2}$. These pathological lesions manifested as thinning of the cortex and depletion of lymphocyte cells in the medulla, accompanied by epithelialization in the medulla of the bursa of Fabricius. Several studies have demonstrated that high density rearing subjects broiler chickens to oxidative stress (Simitzis et al., 2012; Li et al., 2019). Sugiharto et al. (2019) proposed that increased production of free radicals or ROS causes oxidative stress. Oxidative stress may be cytotoxic, and ROS can serve as mediators of cellular injury by interfering with electron transfer, thereby inducing damage to lymphoid cells. Kristeen-Teo et al. (2017) suggested that oxidative stress induced by free radicals in chicken bursa is directly correlated with the depletion of B lymphocytes, which is known to have a direct effect on the competence of humoral immunity.

An interesting finding in this study is that broilers raised at a high stocking density and fed diets supplemented with encapsulated $C$. caudatus leaf extract, particularly at a rate of $1.5 \mathrm{~g} / \mathrm{kg}$, show cortical and lymphocyte cell depletion levels comparable with those of the control. Ahmed et al. (2016) previously showed that propolis containing flavonoids improves the histological structure of the bursa of Fabricius of broilers raised for 42 days. Thus far, no study showing the effect of encapsulated $C$. caudatus leaf extract on the pathological lesions of lymphoid organs in chickens is yet available. Hence, this finding indicates that dietary supplementation with plant extracts containing flavonoids, such those of $C$. caudatus leaf, can improve the immunity of chickens by inducing the proliferation of lymphocyte cells within the immune organs of animals immunosuppressed due to oxidative stress.

In most situations, stress is associated with increased SOD and MDA levels, which is a protective response of broilers against the excessive production of free radicals (Akbarian et al., 2016). In the current study, a high stocking density did not correspond to an increase in SOD and MDA levels in the serum of broilers. The exact reason for this finding is not known, but rearing of broilers at a high stocking density from day 15 to day 42 appeared to allow the broilers to acclimatize to their environment; thus, the animals were able to compensate and adjust their antioxidant mechanisms to accommodate stress conditions. Our findings are supported by the work of Mosleh et al. (2018), who reported that antioxidative enzymes and MDA values increase in the early days in long-term-stressed broilers but decline thereafter. A high stocking density usually leads to chronic oxidative stress in broiler chickens (Simitzis et al., 2012). Regardless of the high stocking density effect, dietary supplementation with encapsulated $C$. caudatus leaf extract elevated the level of SOD of broilers in the present study. While corresponding reports on broilers are scarce, a study on mice showed that dietary administration of $C$. caudatus leaf extract increases SOD activity in the lungs (Abdullah et al., 2015). Abdullah et al. (2015) also reported that C. caudatus leaf extract generally decreases MDA lev- els when administered at doses of 100 and $500 \mathrm{mg} / \mathrm{kg}$ but increases the levels of this oxidative stress marker in the lungs when administered at $1,000 \mathrm{mg} / \mathrm{kg}$. This finding suggests that $C$. caudatus leaf extract could defend against free radicals at lower doses but acts as a pro-oxidant when administered at higher levels. At high doses, C. caudatus may also be metabolized into a toxic metabolite that could damage cells, resulting in elevated MDA levels (Abdullah et al., 2015).

In conclusion, a high stocking density increases erythrocyte, hematocrit, leukocyte, and lymphocyte counts, which seems to be an adaptive response of broilers to enhancements in metabolic rate and physiological stress. Stress due to a high stocking density damages the bursa of Fabricius. Supplementation with encapsulated C. caudatus leaf extract, especially at a rate of $1.5 \mathrm{~g} / \mathrm{kg}$, alleviates cortical and lymphocyte cell depletion in broilers. Regardless of the stocking density effect, dietary supplementation with 0.5 and $1.0 \mathrm{~g} / \mathrm{kg}$ encapsulated C. caudatus leaf extract could increase the daily weight gain of broilers.

\section{Acknowledgment}

This study was financed by the Faculty of Animal and Agricultural Sciences, Universitas Diponegoro (Project No. FPP/2020).

\section{References}

Abdullah A., Dhaliwal K.K., Roslan N.F.F., Lee C.H., Kalaiselvam M., Radman H.M., Saad Q.H.M., Yusof K., Jaarin K. (2015). The effect of Cosmos caudatus (Ulam Raja) on detoxifying enzymes in extrahepatic organs in mice. J. App. Pharm. Sci., 5: 82-88.

Abo-Alqassem Z.M., Ahmed S.A., Ahmed E.A., El-Iraqi K.G. (2018). Effect of different stocking densities as an environmental stressing factor on broiler behaviour and performance. Benha Vet. Med. J., 34: 51-65.

Abudabos A.M., Samara E.M., Hussein E.O., Al-Ghadi A.Q.M. AlAtiyat R.M. (2013). Impacts of stocking density on the performance and welfare of broiler chickens. Ital. J. Anim. Sci., 12: 66-71.

Ahmed O.B., Mahmoud M., Mahmoud U., El-Bab M.F. (2016). Histomorphological changes associated with different doses of Chinese propolis in the bursa Fabricius of chickens. J. Adv. Vet. Res., 6: $1-6$.

Akbarian A., Michiels J., Degroote J., Majdeddin M., Golian A., De Smet S. (2016). Association between heat stress and oxidative stress in poultry; mitochondrial dysfunction and dietary interventions with phytochemicals. J. Anim. Sci. Biotechnol., 7: 37.

Astaneh I.Y., Chamani M., Mousavi S.N., Sadeghi A.A., Afshar M.A. (2018). Effect of stocking density on performance and immunity in Ross 308 broiler chickens. Kafkas Univ. Vet. Fak. Derg., 24: 483-489.

Cheng S.H., Barakatun-Nisak M.Y., Anthony J. (2015). Potential medicinal benefits of Cosmos caudatus (Ulam Raja): A scoping review. J. Res. Med. Sci., 20: 1000-1006.

Gholami M., Chamani M., Seidavi A., Sadeghi A.A., Aminafschar M. (2020). Effect of stocking density and climate region on performance, immunity, carcass characteristics, blood constitutes, and economical parameters of broiler chickens. Braz. J. Anim. Sci., 49: $1-16$.

Hosseini-Vashan S.J., Golian A., Yaghobfar A. (2015). Growth, immune, antioxidant, and bone responses of heat stress-exposed 
broilers fed diets supplemented with tomato pomace. Int. J. Biometeorol., 60: 1183-1192.

Houshmand M., Azhar K., Zulkifli I., Bejo M.H., Kamyab A. (2012). Effect of prebiotic, protein level and stocking density on performance, immunity, and stress indicators of broiler. Poultry Sci., 91 : 393-401.

Iskender H., Yenice G., Dokumacioglu E., Kaynar O., Hayirli A., Kaya A. (2016). The effects of dietary flavonoid supplementation on the antioxidant status of laying hens. Rev. Bras. Cienc Avic, 18: 663-668.

Isroli I., Yudiarti T., Widiastuti E., Sugiharto S. (2017). Probiotic $B a-$ cillus plus vitamins and minerals enhanced haemoglobin values and relative weight of ileum and improved feed conversion ratio of broilers during brooding period. Livest. Res. Rural Dev., 29: 11.

Jeong S.B., Kim Y.B., Lee J.W., Kim D.H., Moon B.H., Chang H.H., Choi Y.H., Lee K.W. (2020). Role of dietary gamma-aminobutyric acid in broiler chickens raised under high stocking density. Anim. Nutr., 6: 293-304.

Jeyakumari A. (2016). Microencapsulation of bioactive food ingredients and controlled release - a review. MOJ Food Process. Tech. 2: $1-9$.

Karimy M.F., Julendra H., Sofyan Damayanti P. (2013). Efektifitas ekstrak daun kenikir (Cosmos caudatus), daun mengkudu (Morinda citrifolia), dan tepung cacing tanah (Lumbricus rubellus) dalam sediaan granul larut air sebagai koksidiostat alami terhadap infeksi Eimeria tenella pada ayam broiler (in Indonesian). JITV, 18: 88-98.

Kiernan J.A. (2015). Histological and histochemical methods. Butterworth/Heinemann, Oxford, 5th. ed.

Kim D.W., Hong E.C., Kim J.H., Bang H.T., Choi J.Y., Ji S.Y., Lee W.S., Kim S.H. (2015). Effect of dietary quercetin on growth performance, blood chemical parameter, immunoglobulin and blood antioxidant activity in broiler chicks (in Korean). Korean J. Poult. Sci., 42: 33-40.

Kristeen-Teo Y.W., Yeap S.K., Tan S.W., Omar A.R., Ideris A., Tan S.G., Alitheen N.B. (2017). The effects of different velogenic NDV infections on the chicken bursa of Fabricius. BMC Vet. Res., 13: 151 .

Li W., Wei F., Xu B., Sun Q., Deng W., Ma H., Bai J., Li S. (2019) Effect of stocking density and alpha-lipoic acid on the growth performance, physiological and oxidative stress and immune response of broilers. Asian-Australas. J. Anim. Sci., 32: 1914-1922.

Liliswarianis N., Musa N.L.W., Zain M.Z.M.W., Kasim J., Karim S.A. (2011). Preliminary studies on phytochemical screening of ulam and fruit from Malaysia. E-J. Chem., 8: 285-288.

Mayo M.A. (2002). Virus taxonomy-Houston. Arch Virol., 147: 10711076.

Mishra M. (2016). Materials of natural origin for encapsulation, In: Handbook of encapsulation and controlled release, Mishra M. (Ed.). USA, CRC Press Taylor \& Francis Group, pp 493.

Mosleh N., Shomali T., Nematollahi F., Ghahramani Z., Khafi M.S.A., Namazi F. (2018). Effect of different periods of chronic heat stress with or without vitamin $C$ supplementation on bone and selected serum parameters of broiler chickens. Avian Pathol., 47: 197-205.

Nwaigwe C.U., Ihedioha J.I., Shoyinka S.V., Nwaigwe C.O. (2020) Evaluation of the hematological and clinical biochemical markers of stress in broiler chickens. Vet. World, 13: 2-8.

Oke O.E., Oso A., Iyasere O.S., Odebowale T., Akanji T., Odusami O., Udehi S., Daramola J.O. (2020). Growth performance and physiological responses of helmeted guinea fowl (Numida meleagris) to different stocking densities in humid tropical environment. Agri. Trop. Subtrop., 53: 5-12

Palizdar M.H., Pourelmi M.R., Tabrizi H.R., Seperh Z. (2016). The impact of acidifier in the diet of broiler chickens grown in high stocking densities on growth performance, immune system, and blood metabolites. J. Anim. Prod., 18: 95-106.

Palizdar M.H., Daylami M.K., Poulermi M.R. (2017). Effects of high stocking density on growth performance, blood metabolites and immune response of broilers (ROSS 308). Livest. Sci., 8: 196-200.
Pang S.F., Yusoff M.M., Gimbun J. (2014). Extraction and microencapsulation of polyphenol from Orthosiphon stamineus leaves. J. Mech. Eng. Sci., 7: 1033-1041.

Park B.S., Um K.H., Park S.O., Zammit V.A. (2018). Growth performance physiological responses of helmeted guinea fowl (Numida meleagris) to different stocking densities in humid tropical environment. Arch. Anim. Breed, 61: 425-432.

Qaid M., Albatshan H., Shafey H., Abudabos A.M. (2016). Effect of stocking density on the performance and immunity of 1-14 d old broiler chicks. Braz. J. Poult. Sci., 18: 1-10.

Reddy D.M., Reddy G.V., Mandal P.K. (2018). Application of natural antioxidants in meat and meat products - a review. Food Nutr. J., 3: 173 .

Reihani S.F.S., Azhar M.E. (2012). Antioxidant activity and total phenolic content in aqueous extracts of selected traditional Malay salads (ulam). Int. J. Food. Res., 19: 1439-1444.

Salami S.A., Majoka M.A., Saha S., Garber A., Gabarrou J.F. (2015). Efficacy of dietary antioxidants on broiler oxidative stress, performance and meat quality: science and market. Avian Biol. Res., 8: $65-78$.

Saleh I., Trisnaningsih U., Dwirayani D., Syahadat R.M., Atmaja I.S.W. (2020). Analisis preferensi konsumen terhadap dua spesies kenikir; Cosmos caudatus dan Cosmos sulphureus (in Indonesian). Mahatani, 3: 196-204.

Selvam R., Sarananakumar M., Suresh S., Sureshbabu G., Sasikumar M., Prashanth D. (2017). Effect of vitamin E supplementation and high stocking density on the performance and stress parameters of broilers. Rev. Bras. Cienc Avic., 19: 587-594.

Simitzis P.E., Kalogeraki E., Goliomytis M., Charismiadou M.A., Trianaphyllopoulus K., Ayoutanti A. (2012). Impact of stocking density on broiler growth performance, meat characteristics, behavioural components and indicators of physiological and oxidative stress. Br. Poult. Sci., 53: 1-5.

Sugiharto S., Turini Y., Isroli I., Widiastuti E., Wahyuni H.I., Sartono T.A. (2019). Fermented feed as a potential source of natural antioxidants for broiler chickens - a mini review. Agric. Conspec. Sci., 84: 313-318.

Taghvaei M., Jafari S.M. (2015). Application and stability of natural antioxidants in edible oils in order to substitute synthetic additives. J. Food Sci. Technol., 52: 1272-1282.

Tóthová C., Sesztakova E., Bielik B., Nagy O. (2019). Changes of total protein and protein fractions in broiler chickens during the fattening period. Vet. World, 12: 598-604.

Trucillo P., Campardelli R., Aliakbarian B., Perego P., Reverchon E. (2018). Supercritical assisted process for the encapsulation of olive pomace extract into liposomes. J. Supercrit. Fluids, 135: $152-159$.

USDA [United States Department of Agriculture] (2020). Livestock and poultry: World markets and trade. Global Market Analysis, Foreign Agricultural Service.

Vongsak B., Sithisarn P., Gritsanapan W. (2012). HPLC quantitative analysis of three major antioxidant components of Moringa oleifera leaf extracts. Planta Med., 78: 1252.

Wang M., Yu B., He J., Yu J., Luo Y.-H., Luo J.-Q., Mao X.-B., Chen D.-W. (2020). The toxicological effect of dietary excess of saccharicterpenin, the extract of camellia seed meal, in piglets. J. Integr. Agr., 10: 211-224.

Yanai T., Abo-Samaha M.I., El-Kazaz S.E., Tohamy H.G. (2018). Effect of stocking density on productive performance, behaviour, and histopathology of the lymphoid organs in broiler chickens. Europ. Poult. Sci., 82: 1-15.

Zhou Y., Mao S., Zhou M. (2019). Effect of the flavonoid baicalein as a feed additive on the growth performance, immunity, and antioxidant capacity of broiler chickens. Poultry Sci., 98: 2790-2799.

Received: 26 II 2021

Accepted: 28 V 2021 